\title{
Analysis on Micro-Course Teaching for Optimizing Higher Vocational P.E Teaching Mode---Taking Gas Volleyball as an Example
}

\author{
Zhuo Ni \\ Humanities Department \\ Guangxi Technological College of Machinery and Electricity \\ Nanning, Guangxi, 530007
}

\begin{abstract}
This paper introduces the concept and features of the micro-course, and for the fabrication, application and management of P.E micro-course, it puts forward the advice and suggestions for the P.E teaching informationization resource construction, in order to seek for the best way of P.E micro-course platform teaching. The result shows that, in P.E course teaching, applying in the micro-course aided teaching mode can better meet students' individualized learning for various knowledge points in P.E subject, which not only can find deficiencies, but also can strengthen the consolidation of knowledge. It is an important complement and expanding resource for traditional $P$.E classroom learning and practice, in order to provide reference for optimizing higher vocational P.E teaching mode.
\end{abstract}

Keywords-micro-course; higher vocational; P.E teaching; gas volleyball;

\section{INTRODUCTION}

This paper, based on the autonomous learning mode of network technology, uses the modern network information technology, in the teaching mode of P.E micro-course, through campus network and course website platform for production and application of P.E micro-course for aided teaching, constructing and perfecting higher vocational P.E micro-course construction and management mechanism, in order to cultivate students' self-exercise habits and enhance their physical quality.

\section{RESEARCH SUBJECT AND METHOD}

\section{A. Research Subject}

The teaching subject is 118 students of the second grade gas volleyball course. For the convenience of research and analysis, we will divide the experimental subjects randomly into two groups, namely, experiment group of 58 people and control group of 60 people.

\section{B. Research Method}

\section{1) Literature Material Method}

Through looking up relevant literature materials and books, grasping relevant micro-course fabrication and teaching mode, we can conduct scientific experiment design concept for analyzing the application mode of P.E microcourse aided P.E teaching.

\section{2) Experiment Method}

The control group adopts traditional P.E teaching cultivation mode and the experiment group adopts microcourse teaching aided practice classroom teaching cultivation mode, in order to ensure the same class times, testing place, content and method of the control group and experiment group.

\section{3) Mathematics Statistics Method}

It adopts variance analysis for the two groups of students' comprehensive ability index performance for differential significance testing after implementing teaching experiment, in order to investigate the teaching effect of different P.E teaching modes. The whole testing index data uses statistics software ASPSS11.0 for statistics processing and quantitative analysis.

\section{RESULT AND ANALYSIS}

\section{A. Existing Problem Analysis of Current Higher} Vocational P.E Course Teaching

1) The Teaching Content Is Monotonous, Lacking of Flexibility.

In teaching content and mode selection, it is old and boring. In the selection of teaching mode, content, time and place, it lacks of flexibility.

\section{2) Traditional Teaching Mode and Backward Thinking}

It adopts the teachers' explanation $\rightarrow$ demonstration $\rightarrow$ students practice $\rightarrow$ correcting wrong actions $\rightarrow$ practice again of traditional teaching mode for teaching, fully ignoring the main body role of students, restricting students' initiative and enthusiasm.

3) Hard to Breakthrough the Important and Difficult Points in Teaching

P.E teaching is the teaching process surrounding action skills, and the important and difficult points of action skills are the main line of P.E teaching.

4) Teaching Information Resource Shortage of Autonomous Learning

With the application of computer information technology in teaching field, they are dispersed in the 
teachers' personal computer, and the resource utilization rate is very low.

\section{B. Advantages of P.E Micro-Course Teaching Mode}

\section{1) Concept}

P.E micro-course refers to a micro online P.E video network learning course of taking video as the main carrier and design development, with time of $15 \mathrm{~min}$, recording the teachers' teaching and learning activity process surrounding a certain knowledge point(important and difficult point) or in the teaching link.

Its core is classroom teaching video, including relevant teaching design, material courseware, teaching reflection, practice testing and student feedback, teachers' comment and other aided teaching resources(Figure 1).

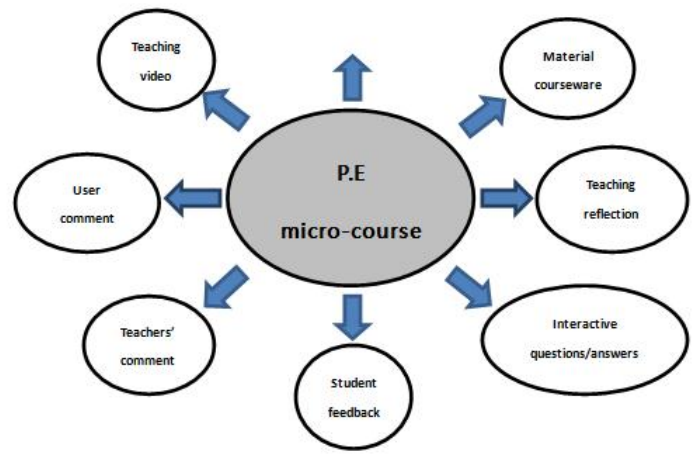

(Figure 1) P.E micro-course teaching resource diagram

\section{2) Features}

\section{a) Short Time}

The teaching video is generally within 15 minutes.

\section{b) Clear Content}

It is recording the teachers' short teaching activity surrounding a certain knowledge point.

\section{c) Much Resource}

Its core is classroom teaching video, and also it includes teaching design and multimedia courseware, teaching reflection, student feedback and practice and testing, etc, in order to create a real learning situation for learners.

\section{3) Construction and Management of P.E Micro-Course}

Because P.E micro-course is a new resource type, its design concept, construction strategy, development technology, application mode are different from traditional resource construction, with a certain uniqueness.

\section{a) Credit Management}

It conducts P.E micro-course credit management for freshmen, setting up 1 credit for each semester, and it is put into P.E teaching outline and teaching management.

\section{b) Micro-Course Platform}

Through the campus network, it opens a "P.E microcourse" platform, and teachers can upload their own works to the website "P.E micro-course base", for students to have independent learning.

c) Incentive Mechanism

At the beginning of the year, the school announced the knowledge point content of P.E subject micro-course construction for teachers to have optional development and fabrication, which is not the same as last year's content knowledge point. Then, the quantity and quality of teachers' fabricated micro-course are put into the school's performance appraisal regulations.

\section{d) Projects}

For the teachers winning the first, second and third price of the college's excellent courseware competition, they will be provided with excellent courseware project support.

\section{Feasibility Analysis}

\section{1) Internet Micro-Era}

Micro-course is to let people use the terminal equipment to study in university or at home.

\section{2) Personalized Learning}

For students, P.E micro-course can better meet the personalized learning of students for knowledge point, learning according to need, which can consolidate the knowledge and complement deficiency, and it is an important complementary and expanding of traditional classroom learning.

\section{Research and Development of Gas Volleyball Micro- Course in Our School}

\section{1) DV Camera and Whiteboard}

It is more suitable for explaining the tactical link.

Fabrication: The first step: for P.E micro-course topic, it conducts detailed teaching design, forming the teaching plan. The second step: it uses tactics demonstration board for teaching process, and it uses DV recorder to shoot the whole process. The third step: it can conduct necessary editing and beautifying for recording video.

\section{2) Screen Recording Software and PPT}

It is more suitable for learning technical movements.

Fabrication: The first step: For the selected teaching knowledge points, we can collect materials and make PPT courseware. The second step: on the computer screen, also, 
it opens the video recording software and teaching PPT, and the coach takes the headset, while demonstrating and explaining, and they can use the marking tool and materials, trying to make the teaching process vivid and interesting. The third step: it conducts necessary processing and beautifying for the recorded teaching video.

\section{3) Creative Design Recording}

Through more intuitive mode, it can attract students' eyeball for recording.

Self design: DV camera, screen recording software and PPT courseware

It takes the technical teaching of gas volleyball as an example for fabrication and application introduction, adopting personal creative design recording method: DV camera, screen recording software and PPT courseware (Figure 2).
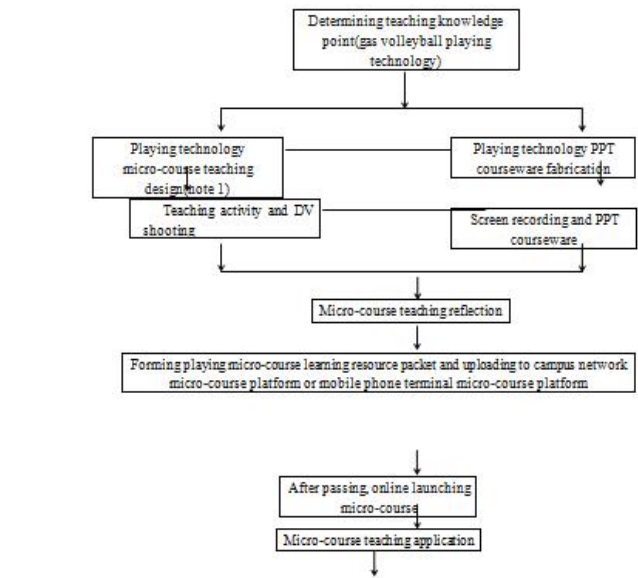

\begin{tabular}{|c|c|c|c|c|c|}
\hline$\sqrt{ }$ & $\downarrow$ & $\downarrow$ & & & \\
\hline $\begin{array}{c}\begin{array}{c}\text { Online learning } \\
\text { Note } 2)\end{array} \\
\end{array}$ & $\begin{array}{l}\text { Evaluation and } \\
\text { comments CNote }\end{array}$ & \begin{tabular}{|c|} 
Student festhack \\
(Note 4)
\end{tabular} & $\begin{array}{c}\text { Interactive } \\
\text { question answer } \\
\text { (Note 5) }\end{array}$ & \begin{tabular}{c|} 
Reverse \\
Classoom Note \\
6 )
\end{tabular} & $\begin{array}{l}\text { Self-exerdise } \\
\text { (Note 7) }\end{array}$ \\
\hline
\end{tabular}

(Figure 2)Gas volleyball playing technology micro-course teaching fabrication and application

[Note 1]As the online learning video resource, in design, it should consider more about the application effect of micro-course teaching. Taking gas volleyball playing as an example, it makes a simple introduction. DV shooting and teaching activity: we can let two students conduct wrong action demonstration and corresponding improvement and improving practice method for DV shooting, screen recording and PPT courseware explanation: Through PPT courseware design, it combines with the important and difficult point action links of playing.

[Note 2]It not only can provide an independent learning platform for students, but also provide a mutual learning opportunity for peer teachers.

[Note 3] Students conduct evaluation for micro-course teaching and teachers' comment, which are good for improving teachers' micro-course teaching quality.

[Note 4]Student feedback is good for teachers and students to mutually monitor "learning process", in order to achieve the purpose of adjusting timely.
[Note 5]Students can obtain teachers and classmates' help to obtain the knowledge of playing technology action aspect.

[Note 6]They conduct self-learning inside and outside class, and they learn and practice with teachers in the ball field.

[Note 7]They choose their interested content for independent learning, and they can pause and replay when they don't understand the technical points or action links, in order to better cultivate students' self-exercise habits.

\section{E. Teaching Effect of P.E Micro-Course}

Through half a year's experiment teaching, it will conduct comprehensive ability testing of gas volleyball course for the two groups of students at the end of the semester, and the content includes: technical grasping ability, physical quality, self-training ability, physical quality, self-training ability, interest, interpersonal skills. The examination results of experiment group and control group are shown as follows(Table 1).

Table 1 TWO GROUPS OF COMPREHENSIVE ABILITY INDEX PERFORMANCE COMPARISON AFTER EXPERIMENT

\begin{tabular}{|c|c|c|c|c|c|}
\hline & \multicolumn{2}{|c|}{ 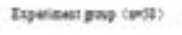 } & \multicolumn{3}{|c|}{ Canno ond tors? } \\
\hline Aresp & socon & Scoted tensix & 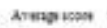 & 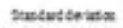 & E Dibwe:nuera \\
\hline Pktaici pupubary & wss & $\$ 4$ & n: 19 & 957 & mas \\
\hline sefturelu baly & tos & 3925 & n1s: & +44 & $x 04$ \\
\hline serenta & st: & 738 & s1. & t:int & 20005 \\
\hline 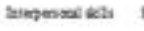 & Ats & 102 & rat & $\cos 2$ & xots \\
\hline 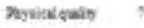 & 74 & 34 & $\mathbf{6 1}$ & 421 & mos \\
\hline
\end{tabular}

From Table 1, two groups of students' ability performance index doesn't have significant difference apart from physical quality, and other items have significant difference. Thus, in the teaching process, it adopts microcourse aided teaching mode, which is better than traditional P.E teaching mode.

\section{CONCLUSION AND SUGGESTIONS}

\section{A. Conclusion}

For students, P.E micro-course can better meet the personalized learning of various knowledge points in P.E subject, which can avoid deficiencies and also strengthen and consolidate the knowledge.

P.E micro-course website can summarize and exchange the teachers' excellent teaching resources, which not only can provide an independent learning platform for students, but also provide a chance for mutual learning for peer teachers. 
In gas volleyball teaching process, it adopts microcourseaided teaching mode, it can better improve students' comprehensive ability level.

\section{B. Suggestions}

The school micro-course construction should breakthroughthe single mode of real classroom teaching situation for class shooting recording, developing multiple micro-course teaching recording mode, conduct independent innovation, grasping students' interest and attention, with focus content to students, which can let students learn the most important content in the shortest time, and students can strengthen their ability in learning resource and question answering.

Improving micro-course teaching network information platform construction

Strengthening the promotion and application of higher vocational micro-course teaching, fabricating corresponding management regulations, putting micro-course learning into students' credit confirmation, making micro-course fabrication into teachers' performance appraisal.

We should strengthen teachers' micro-course development technology training, with bold innovation and not sticking to one pattern, improving the overall quality of micro-course.

\section{ACKNOWLEDGMENT}

Won the first prize of education department of Guangxi $10^{\text {th }}$ Middle School Students' Sports Meeting Thesis Evaluation; Won the third prize of department of Guangxi university software application informationization thesis evaluation.

\section{REFERENCES}

[1] Li Bin, Autonomous learning teaching mode design and implementation based on network technology[J]. Journal of Suzhou College, 2011,26(6).

[2] Yuan Chun, Ji Shaofeng. Using multimedia network technology to guide students to have autonomous learning[J]. Huazhang, 2012,34:181

[3] Lin Xiangyang, Zhou Hongmei. Study on P.E remote teaching mode based on network environment[J]. Journal of Beijing P.E University,2005,28(4).

[4] Wu Zhenzhen. How to strengthen students' independent exercise consciousness in higher vocational P.E teaching $[\mathrm{J}]$. Examination Weekly, 2012,76.

[5] $\mathrm{Hu}$ Tiesheng. Development and reflection of regional excellent micro-course resource[J].Middle School and Primary School Information Technology Education, 2013,4.

[6] Hu Tiesheng. Middle school and primary school excellent "Microcourse" resource development region practice and enlightenment[J]Chinese Education Informationization, 2012,22.
[7] Liang Lening, Cao Qiaoqiao, Zhang Baohui. Micro-course design mode study[J]. Open Education Research,2013,19(1).

[8] Yuan Ye, Li Minghua, Xu Peng,et al. Study on development and application of P.E feature information database in digital environment[J].Journal of Nanjing P.E College(Social and Scientific Edition),2011,25

[9] She Minke, He Yanhui, Pan Nianli. Study on P.E multimedia teaching courseware application effect experiment in different teaching modes[J]Journal of Wuhan P.E College,2005,32(2).

[10] Wei Hua. Healthy exercise technical course network teaching platform construction[J]. Journal of Beijing P.E University, 2010,33(1). 